5 Kennedy RL, Darne J, Davies R, Price A. Thyrotoxicosis and hyperemesis gravidarum associated with a serum and hyperemesis gravidarum associated with a serum activity which stimulates hum

6 Lao TTH, Chin RKH, Cockram CS, Panesar NS Transient hyperthyroidism in hyperemesis gravidarum. $\mathfrak{f} R$ Soc Med 1986; 79: 613-5.

7 Goodwin TM, Montoro M, Mestman JH. Transient hyperthyroidism and hyperemesis gravidarum: clinical aspects. Am f Obstet Gynecol 1992; 167: 648-52.

8 Wilson $\mathrm{R}$, McKillop JH, MacLean M, et al. Thyroid function tests are rarely abnormal in patients with severe hyperemesis gravidarum. Clin Endocrinol 1992; 37: $331-4$.

9 Taylor R Successul management of hyperemesis gravidarum using steroid therapy. Of Med 1996; 89: $103-7$.

10 Krentz AJ, Redman H, Taylor KG. Hyperthyroidism associated with hyperemesis gravidarum. Br $f$ Clin Pract 1994; 48: $75-6$.
11 Bartalena L, Grasso L, Brogioni S, Aghini-Lombardi F, Braverman LE, Martino E. Serum interleukin-6 in amiodarone induced thyrotoxicosis. F Clin Endocrinol Metab 1994; 78: 423-7.

12 Beckett GJ, Kellett HA, Gow SM, Hussey AJ, Hayes JD, Toft AD. Raised plasma glutathione $S$-transferase values in hyperthyroidism and in hypothyroid patients receiving thyroxine replacement: evidence for hepatic damage. $B M F$ 1985; 291: 427-31.

13 Kauppila A, Huhtaniemi I, Ylikorkala O. Raised serum human chorionic gonadotrophin concentrations in hyperemesis gravidarum. BMf 1979; i: 1670-1.

\title{
Acute fulminant neuropathy in a patient with Churg-Strauss syndrome
}

Department of
Medicine, Queen
Elizabeth Hospital,
Kowloon, Hong Kong
Division of
Neurology
KKP Ng
HM Yeung
HM Chan
CK Wong
PCK Li
Department of
Pathology
KT Loo

Accepted 27 June 1996

KKP Ng, HM Yeung, KT Loo, HM Chan, CK Wong, PCK Li

\begin{abstract}
Summary
We report a patient with an acute neuropathy initially mimicking Guillain-Barré syndrome, both clinically and electrophysiologically. Persistent eosinophilia, positive antineutrophil cytoplasmic antibody and eosinophilic vasculitis in sural nerve biopsy later confirmed Churg-Strauss syndrome. Since vasculitic neuropathy can present in an acute and fulminant form, the role of early antibody testing and sural nerve biopsy in atypical cases of acute neuropathy is emphasized.
\end{abstract}

Keywords: Churg-Strauss syndrome, allergic granulomatous angiitis, neuropathy, Guillain-Barré syndrome

The peripheral nervous system is commonly involved in systemic vasculitic diseases such as polyarteritis nodosa, Churg-Strauss syndrome, Wegener's granulomatosis and cryo- globulinaemia. The incidence can be greater than $75 \%{ }^{1}$ Presentation is usually as mononeuritis multiplex, asymmetrical polyneuropathy, chronic distal symmetrical sensory or sensorimotor polyneuropathy. ${ }^{1-4}$ An acute fulminant involvement of all peripheral nerves in the early phase of illness is rarely reported.

\section{Case report}

A 58-year-old man had late-onset asthma for the past two years which was well controlled with a regular inhalational bronchodilator. $\mathrm{He}$ enjoyed good health otherwise. For six weeks before admission, he had had general malaise, night sweating, low-grade fever and weight loss. His general practitioner diagnosed pulmonary tuberculosis following a chest X-ray which showed bilateral apical infiltrates. He received anti-tuberculous drugs but stopped taking them after three days because of gastrointestinal upset. $\mathrm{He}$ was then admitted

Table Results of nerve conduction study on day 3

\begin{tabular}{|c|c|c|c|c|c|c|c|}
\hline Nerve & $\begin{array}{l}D M L \\
(m s)\end{array}$ & $\begin{array}{l}C M A P \\
(m V)\end{array}$ & $\begin{array}{l}M N C V \\
(m / s)\end{array}$ & $\begin{array}{l}\text { Conductional } \\
\text { block }\end{array}$ & F-wave & $\begin{array}{l}S N A P \\
(\mu V)\end{array}$ & $\begin{array}{l}S N C V \\
(\mathrm{~m} / \mathrm{s})\end{array}$ \\
\hline $\mathbf{R}$ median & 3.7 & $4.9^{\star}$ & 52 & absent & normal & 10 & 45 \\
\hline $\mathrm{L}$ median & 3.9 & $2.3^{\star}$ & - & complete & absent & $3^{\star}$ & 46 \\
\hline R ulnar & 2.6 & $1.1^{\star}$ & $48^{\star}$ & absent & absent & $4^{\star}$ & 48 \\
\hline L ulnar & 3.2 & 11.0 & 52 & absent & prolonged & $5^{\star}$ & 46 \\
\hline $\mathrm{R}$ peroneal & 3.5 & $0.6^{\star}$ & 42 & absent & prolonged & & \\
\hline $\mathrm{L}$ peroneal & 4.2 & $1.3^{\star}$ & 41 & partial & absent & & \\
\hline $\mathrm{R}$ posterior tibial & 6.3 & $0.07^{\star}$ & 60 & partial & absent & & \\
\hline L posterior tibial & 5.1 & $0.7^{\star}$ & 41 & partial & absent & & \\
\hline$R$ sural & & & & & & 7 & 57 \\
\hline L sural & & & & & & 13 & 50 \\
\hline
\end{tabular}

Abbreviations: $\mathrm{R}=$ right; $\mathrm{L}=$ left; $\mathrm{DML}=$ distal motor latency; $\mathrm{CMAP}=$ compound muscle action potential amplitude; $\mathrm{MNCV}=$ motor nerve conduction velocity; $\mathrm{SNAP}=$ sensory nerve action potential amplitude; $\mathrm{SNCV}=$ sensory nerve conduction velocity; *abnormal values 
into hospital for progressive weakness of limbs over two weeks which rendered him unable to walk for two days. Numbness was present in the extremities. There was no bulbar or sphincter disturbance.

Physical examination showed an afebrile, conscious and alert man with intact cranial nerves. Motor examination showed a symmetrical decrease in muscle power: upper limbs wrist flexors and extensors (grade 3), small hand muscles (grade 2), elsewhere in upper limbs (grade 5); lower limbs - hip, knee and ankle extensors (grade 5), hip and knee flexors (grade 4), ankle flexors and foot muscles (grade 3). Tendon reflexes were hyporeflexic in the upper and areflexic in the lower limbs. Sensory examination showed a glove and stocking loss of pinprick sensation; proprioceptive sense was absent in the toes. The patient was able to stand with support. Forced vital capacity was 1.59 litre. Examination of the blood pressure, skin, cardiovascular system, chest and abdomen were normal.

He continued to deteriorate and, by day 2 of hospitalization, could not stand. The results of a nerve conduction study on day 3 are shown in the table. Electromyography showed active denervation changes in the proximal and distal muscles of both upper and lower limbs. Cerebrospinal fluid (CSF) examination showed white blood cells $<1 \times 10^{9} / 1$, red blood cells $4 \times 10^{9} / 1$, protein $0.18 \mathrm{~g} / 1$, glucose $4.8 \mathrm{mmol} / 1$ (serum glucose $9.4 \mathrm{mmol} / \mathrm{l}$ ) with no organisms grown. Blood investigations showed haemoglobin $11.6 \mathrm{~g} / \mathrm{dl}$, platelets $524 \times 10^{9} / 1$, white blood cells $21.6 \times 10^{9} / 1$, erythrocyte sedimentation rate (ESR) $113 \mathrm{~mm} / \mathrm{h}$, normal liver and renal function tests except increased globulin $(40 \mathrm{~g} / \mathrm{l})$ and decreased albumin $(27 \mathrm{~g} / \mathrm{l})$. Chest X-ray still showed bilateral apical infiltrates.

With the features of demyelination in nerve conduction study and the CSF findings, a diagnosis of probable Guillain-Barré syndrome was made and five sessions of plasmapheresis were given from day 4 on alternate days. Anti-tuberculous drugs were restarted for the lung infiltrates, with a presumptive diagnosis of pulmonary tuberculosis. His condition stabilised after plasmapheresis; on day 7, examination revealed an increase of his left wrist power to grade 4; other muscles and tendon reflexes remained the same. A low grade fever of $37.5-38.5^{\circ} \mathrm{C}$ and sinus tachycardia of 120 beats/min developed and persisted after admission. Persistent peripheral eosinophilia ranging from 47 to $65 \%$ (11.8$\left.20.6 \times 10^{9} / 1\right)$, and elevation of ESR and serum globulin were also noted. Other investigations showed $\mathrm{HB}_{\mathrm{s}} \mathrm{Ag}$ and $\mathrm{ANF}$ negative, rheumatoid factor positive, C-reactive protein $87.7 \mathrm{mg} / 1$ (normal $<8$ ), normal IgA and IgG but IgM $0.34 \mathrm{~g} / 1$ (normal $0.63-2.77 \mathrm{~g} / \mathrm{l}$ ). Echocardiogram showed a mild global myocardial dysfunction with a small pericardial effusion. Lung function test showed a restrictive pattern.

On day 17, his right wrist power decreased to grade 2 . A repeated nerve conduction study on day 18 revealed non-excitable nerves in all four limbs. Sural nerve biopsy on day 22

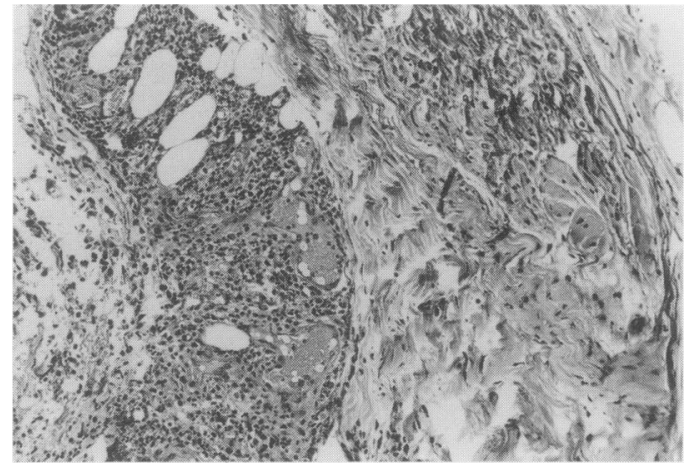

Figure Sural nerve biopsy. Granuloma replacing blood vessel (right) in perineurium of sural nerve seen adjacent to nerve fascicles with prominent eosinophilic infiltration (left) (Haematotoxylin \& Eosin)

\section{Learning/summary points \\ - systemic vasculitis, including Churg-Strauss syndrome, can present initially as an acute fulminant generalised neuropathy \\ - features of demyelination in nerve conduction study can be seen in vasculitic neuropathy \\ - fever, prominent sensory signs, peripheral eosinophilia and involvement of other organs are uncommon in Guillain-Barré syndrome \\ - a positive ANCA titre points towards a diagnosis of vasculitic neuropathy}

showed an extensive active demyelination and its vasa nervosa was involved by granulomatous inflammation with prominent eosinophilic infiltration (figure). Subsequent antineutrophil cytoplasmic antibody (ANCA) titre was positive at $1: 20$ with a perinuclear uptake pattern (pANCA) and myeloperoxidase level was $100 \%$ (normal <3.9\%). He then developed acute respiratory failure due to pulmonary haemorrhage and required mechanical ventilation. A diagnosis of Churg-Strauss syndrome was made and plasmapheresis was restarted on day 24, pulse intravenous methylprednisolone was given at $1 \mathrm{~g}$ daily for three days from day 25 , and oral cyclophosphamide $100 \mathrm{mg} /$ day from day 29. Despite the aggressive treatment, the patient developed acute renal failure requiring haemodialysis, paralytic ileus with fresh rectal bleeding (rectal biopsy showed glandular atrophy and lamina propria fibrosis indicated the presence of ischaemia) and convulsions. His clinical course was further complicated by pneumonia and urinary tract infection. He finally succumbed on day 79 .

\section{Discussion}

Retrospectively, our patient satisfied the diagnostic criteria of Churg-Strauss syndrome ${ }^{5}$ with a prodromal phase of asthma, an infiltrative phase of pulmonary infiltrates, and a vasculitic phase involving the peripheral and central nervous system, heart, lungs, kidneys and gastrointestinal tract, supported by peripheral eosinophilia, positive pANCA and characteristic sural nerve biopsy findings. However, most of these features of the full- 
blown syndrome were not evident at the presentation of his generalised neuropathy. Unfortunately, his apical lung infiltrates, ill health, fever and raised ESR were initially thought due to pulmonary tuberculosis in an endemic area. His acute generalised neuropathy was initially thought to be GuillainBarré syndrome which has been previously reported to develop after pulmonary tuberculosis. This presumptive diagnosis was further supported by the features of demyelination in nerve conduction studies. Nevertheless, prominent sensory signs, persistent peripheral eosinophilia and fever were atypical, and the involvement of other organs is not seen in Guillain-Barré syndrome. ${ }^{6}$

The correct diagnosis was helped by the positive blood test for ANCA and characteristic findings on sural nerve biopsy. In vasculitic neuropathy, features in the nerve conduction study suggestive of demyelination, such as absent or prolonged F-wave responses,

1 Moore PM, Fauci AS. Neurologic manifestations of systemic vasculitis: a retrospective and prospective study of the clinicopathologic features and responses to therapy in 25 patients. Am F Med 1981; 71: 517-24.

2 Chalk CH, Dyck PJ, Conn DL. Vasculitic neuropathies. In: Dyck PJ, Thomas PK, Griffin JN, Low PA, Poduslo JF, eds. Peripheral neuropathy, 3rd edn. Philadelphia and London: WB Saunders, 1993; pp 1424-36.

3 Kissel JT, Slivka AP, Warmolts JR, Mendell JR. The clinical spectrum of necrotizing angiopathy of the peripheral nervous system. Ann Neurol 1985; 18: $251-7$.

4 Bouch P, Leger JM, Travers MA, Cathala HP, Castaigne P. Peripheral neuropathy in systemic vasculitis: clinical and electrophysiologic study of 22 patients. Neurology 1986; 36: 1598-602.

5 Mass A, Hunder GG, Lie JT, Michel BA, Bloch DA. The

American College of Rheumatology 1990 criteria for the classification of Churg-Strauss syndrome (allergic granulomatosis and angiitis). Arthritis Rheum 1990; 33: 1094-100. the presence of intermediate conduction blocks and slow motor conduction velocities have been reported and are attributed to ischaemia. ${ }^{7,8} \mathrm{CSF}$ examination is usually normal in vasculitic neuropathy and the early phase of Guillain-Barré syndrome. ${ }^{6}$ In differentiating a vasculitic neuropathy from Guillain-Barré syndrome, there may be difficulties in arriving at a correct diagnosis in the absence of other clinical features of vasculitis or when only atypical features are present. Although not diagnostic of vasculitic neuropathies, ${ }^{9}$ a positive blood test for ANCA is present in more than $60 \%$ of patients with Churg-Strauss syndrome $^{10}$ and, together with positive sural nerve biopsy findings, this helps to confirm the diagnosis of vasculitic neuropathy earlier, guide the treatment and improve the prognosis of the patient. We therefore recommend conducting a blood test for ANCA and early sural nerve biopsy in atypical cases of acute neuropathy.

6 Hughes RAC. Guillain-Barré syndrome Heidelberg: Springer-Verlag, 1990

7 Dyck PJ, Benstead TJ, Conn DL, Clarke Stevens J, Windebank AJ, Low PA. Nonsystemic vasculitic neuropathy. Brain 1987; 110: 843-53.

8 Ropert A, Metals S. Conduction block in neuropathies with necrotizing vasculitis. Muscle Nerve 1990; 13: 102-5.

9 Chalk CH, Homburger HA, Dyck PJ. Anti-neutrophil cytoplasmic antibodies in vasculitic neuropathies. Neurology 1993; 43: $1826-7$

10 Guillevin L, Visser H, Noel LH, et al. Antineutrophil cytoplasmic antibodies in systemic polyarteritis nodosa with and without hepatits $B$ virus infection and Churg-S with syndrome - 62 patients. $f$ Rheumatol 1993; 20: 1345-9. 